\title{
Slik kan jordmorstudenter lære kunnskapsbasert praksis
}

Jordmorutdanningen ved Universitetet i Tromsø har prøvd ut et nytt undervisningsopplegg i kunnskapsbasert praksis. Her er lærernes erfaringer og studentenes evalueringer.

\section{Forfattere}

\section{Gry Skogheim}

Universitetslektor

Helsefakultetet, Universitetet i Tromsø - Norges arktiske universitet

Sigrun Kongslien

Universitetslektor og studieleder

Helsefakultetet, Universitetet i Tromsø - Norges arktiske universitet

Tove Aminda Hanssen

Fag- og forskningssykepleier og professor

Hjerte- og lungeklinikken, Universitetssykehuset Nord-Norge og Universitetet i Tromsø Norges arktiske universitet

kunnskapsbasert praksis

Sykepleien 2019 107(79726)(e-79726)

DOI: https://doi.org/10.4220/Sykepleiens.2019.79726

\section{Hovedbudskap}

Det er nasjonale og internasjonale føringer for at all helsetjeneste skal være kunnskapsbasert. Her beskriver vi vår erfaring med å undervise i kunnskapsbasert praksis (KBP) i jordmorutdanningen. Jordmorstudenter opplever at det kan være krevende for dem å prioritere læringsaktiviteter i KBP. En årsak er jordmorutdanningens omfattende læringsmål, herunder krav i form av EØS-direktiver, som er nødvendige for å få autorisasjon som jordmor. En annen utfordring er å sikre lærerkompetansen i KBP. 
Kunnskapsbasert praksis (KBP) har vokst frem som en «motbevegelse» mot en helsetjeneste som i stor grad ikke har basert virksomheten på best tilgjengelige forskningskunnskap (1). Kunnskapsbasert praksis «er å ta faglige avgjørelser basert på systematisk innhentet forskningsbasert kunnskap, erfaringsbasert kunnskap og pasientens ønsker og behov i den gitte situasjonen» (2). Kunnskapsbasert praksis-modellen er illustrert i figur 1.

KBP-begrepet rommer ulike kunnskapskilder som alle er essensielle for kvaliteten på helseprofesjonell fagutøvelse. KBP er et mål i nasjonal helsetjeneste og er løftet frem både av kunnskaps- og helsemyndighetene $(3,4)$.

For å nå målet er innholdet i helseprofesjonsutdanningene, som jordmorutdanningen er et eksempel på, sentralt. Samtidig viser forskning at helseprofesjonelle med kompetanse i KBP opplever hindringer som vanskeliggjør kunnskapsbasert praksisutøvelse, for eksempel tidsmangel og manglende evne til å lese forskning på engelsk (5-9).

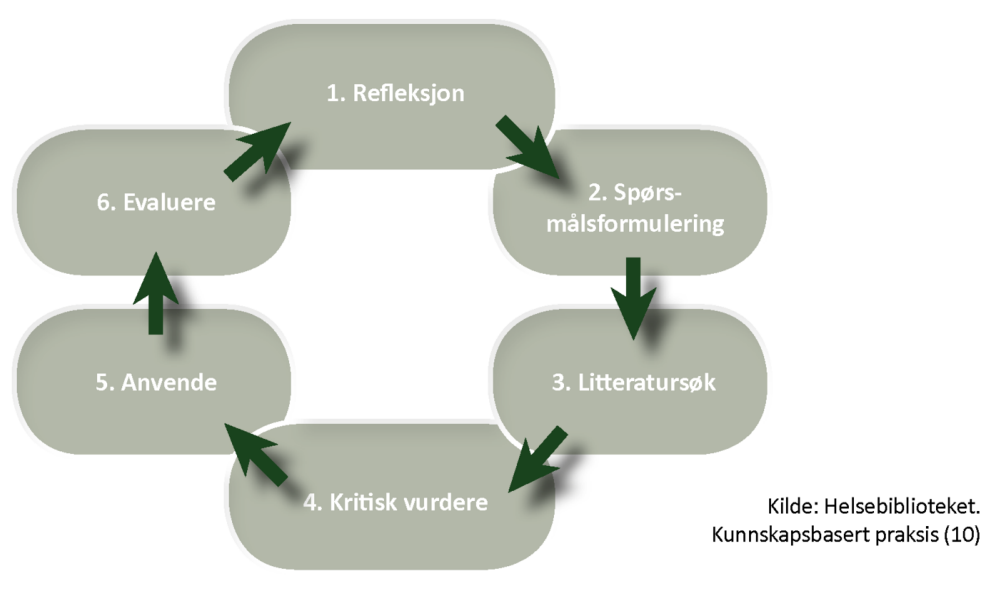


Verdens helseorganisasjon peker også spesielt på behovet for å utvikle og styrke en evidensbasert, jordmorfaglig utøvelse i Europa, noe som kan ses i sammenheng med innholdet i jordmorutdanninger (11).

I jordmorutdanningen ved Universitetet i Tromsø Norges arktiske universitet (UiT) har vi i en årrekke inkludert erfaringskunnskap og til dels brukermedvirkning i undervisningen. Forskningskunnskapen, derimot, har vært innlemmet i undervisningen på et mer usystematisk vis.

I 2014 startet vi et undervisningsopplegg i KBP i jordmorutdanningen ved UiT. Målet var at jordmorstudentene skulle tilegne seg kunnskap i KBP gjennom å trene på å formulere søkbare, faglige spørsmål, utføre litteratursøk og finne forskning, vurdere forskningsartikler med ulike forskningsmetoder eller -design og integrere resultater fra forskning i sin videre læring.

I denne artikkelen beskriver vi undervisningsopplegget vårt i kunnskapsbasert praksis samt studentenes og lærernes erfaringer.

\section{Beskrivelse av undervisningsopplegget}

Opplegget bygger i stor grad på nasjonale ressurser innen KBP ved at lærerne deltar på nasjonal workshop i regi av Kunnskapssenteret samt bruker KBP-nettkurs og norske lærebøker $(1,2,10)$. Vi har anvendt ulike undervisningsformer etter inspirasjon fra andres erfaringer og anbefalinger $(2,12)$.

Det kan være gunstig for læringen i KBP å veksle mellom læringsressurser på nett og andre undervisningsformer $(13,14)$. En slik veksling med selvstudium først og dernest klasseromsundervisning og diskusjon kalles for flipped classroom (15). 
Undervisningen vår besto av introduksjonsforelesning av læreren, KBP-nettkurs (10) og gruppearbeid med å utarbeide et faglig, søkbart spørsmål ved hjelp av PICOT: Problem/patient, (problem eller pasient), Intervention (intervensjon), Comparison (sammenlikning), Outcome (utfallsmål eller resultat) og Time (tid).

\section{三 «Det kan være gunstig for læringen i KBP å veksle mellom læringsressurser på nett og andre undervisningsformer. "}

Videre besto undervisningen av artikkelsøk med bibliotekar, gruppearbeid med artikkelgranskningen og fremlegg av gruppearbeidet i plenum med lærerne til stede. KBP-nettkurset var beregnet til fire-fem timers arbeid (10). Det var ikke tid eller ressurser til å inkludere trinn 5 , anvendelse og trinn 6 , evaluering. I figur 2 illustrerer vi undervisningsopplegget.

Under gruppenes utarbeidelse av PICOT og artikkelgranskning veiledet første- og andreforfatterne. Artikkelgranskningen ble i tillegg understøttet av sjekklister som er tilgjengelige via Helsebilioteket (10).

Figur 2. Illustrasjon av undervisningsopplegget

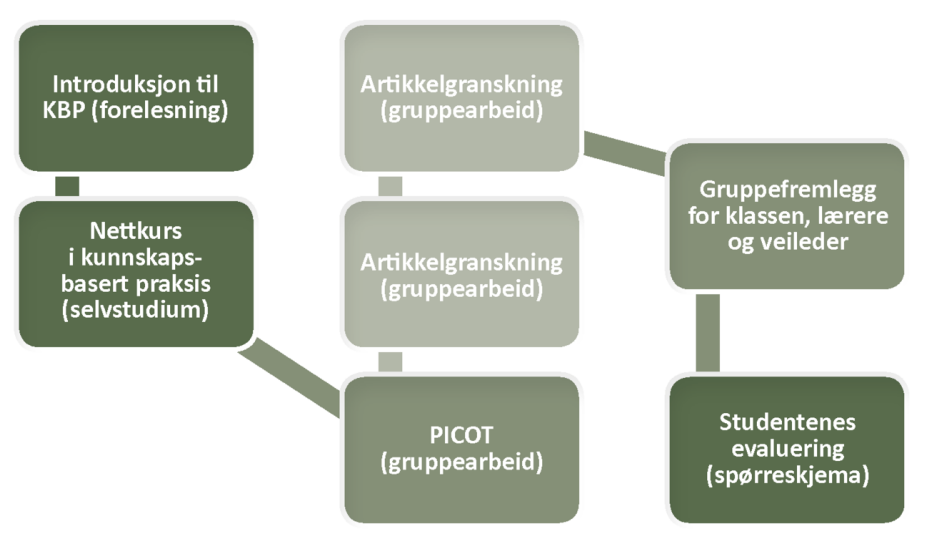


Etter endt undervisningsopplegg var det frivillig for studentene å fylle ut et evalueringsskjema. I

evalueringen stilte vi spørsmål om

undervisningsopplegget og studentenes egne

læreforutsetninger, veiledningsbehov og læringsutbytte (tabell 1). Et spørreskjemadesign med faste svaralternativer er en velegnet metode for å kartlegge respondenters vurderinger (16).

Evalueringen ble gjennomført anonymt i

klasserommet på et papirbasert spørreskjema med gitte svaralternativer, og med læreren til stede.

Svaralternativene i evalueringen var «1: i stor grad», «2: tilfredsstillende», «3: i noen grad» og «4: i liten grad».

I evalueringsskjemaet var det anledning til å gi kommentarer på åpne spørsmål. Det var sparsomt med kommentarer, og de er ikke blitt selvstendig analysert, men anvendes i diskusjonen for å eksemplifisere og belyse kvantitative resultater.

Samtlige 43 studenter (100 prosent) som var til stede under evalueringen, har svart på spørreskjemaet. Vi orienterte om at informasjonen fra skjemaene ville bli brukt i en artikkel.

Første del av evalueringsskjemaet var rettet mot studentenes opplevde forutsetninger for å følge undervisningen. Hele 77 prosent opplevde at de hadde gode forutsetninger for å følge nettkurset i KBP. Når det gjaldt å definere et faglig spørsmål formulert som PICOT og utføre artikkelsøk, svarte om lag to tredeler av studentene at de hadde gode forutsetninger for å gjøre dette. Mange opplevde det som utfordrende å vurdere vitenskapelige forskningsartikler; hele 54 prosent mente at de hadde noen eller små forutsetninger for å gjøre dette. 
Andre del av evalueringsskjemaet var rettet mot

hvordan studentene opplevde utbyttet av veiledningen

og undervisningsformen. Det var anledning til å be om

bibliotekarveiledning, og 50 prosent av studentene

benyttet seg av det. To tredeler av dem som ba om

bibliotekarveiledning, opplevde veiledningen som

nyttig.

Alle fikk veiledning fra læreren i de fleste

gruppearbeidsøktene, og halvparten opplevde det som

tilfredsstillende eller svært nyttig. Når det gjaldt

undervisningsform, mente to tredeler at gruppearbeid

passet godt for å oppnå læringsmålene. Samtlige mente at de i deltok mye i gruppearbeidet.

Tabell 1. Studentenes evaluering av undervisningsopplegget og egne forutsetninger for læring.

\begin{tabular}{|c|c|c|c|c|c|}
\hline \multirow[t]{2}{*}{ Spørsmål } & \multirow[t]{2}{*}{$\begin{array}{c}\text { Antall som } \\
\text { har svart }\end{array}$} & \multicolumn{2}{|c|}{$\begin{array}{c}\text { I stor grad / } \\
\text { tilfredsstillende }\end{array}$} & \multicolumn{2}{|c|}{$\begin{array}{l}\text { I noen grad / } \\
\text { i liten grad }\end{array}$} \\
\hline & & $\begin{array}{c}\text { Antall } \\
\text { studenter }\end{array}$ & $\%$ & $\begin{array}{c}\text { Antall } \\
\text { studenter }\end{array}$ & $\%$ \\
\hline 1. Egne forutsetninger for å gjennomføre nettkurs i KBP & 43 & 33 & 77 & 10 & 23 \\
\hline 2. Egne forutsetninger for å formulere PICO & 43 & 28 & 65 & 15 & 35 \\
\hline 3. Egne forutsetninger for å utføre søk & 43 & 28 & 65 & 15 & 35 \\
\hline 4. Egne forutsetninger for å vurdere artikkel kritisk & 43 & 20 & 46 & 23 & 54 \\
\hline 5. I hvilken grad var bibliotekarveiledning til hjelp? & 22 & 14 & 64 & 8 & 36 \\
\hline 6. I hvilken grad passer gruppearbeid for å nå læringsmålene? & 35 & 28 & 80 & 7 & 20 \\
\hline 7. I hvilken grad deltok du i gruppearbeidet? & 36 & 36 & 100 & 0 & 0 \\
\hline 8. I hvilken grad var lærerveiledningen til hjelp? & 30 & 16 & 53 & 14 & 47 \\
\hline
\end{tabular}

\section{Lærerne tok initiativ til justeringer}

På bakgrunn av evalueringsskjemaene fra hvert kull justerte vi opplegget underveis. For det første tok lærerne en mer aktiv rolle, som innebar at vi oppsøkte gruppene for å kartlegge om de trengte veiledning. I tillegg begrenset vi antallet artikler studentene skulle finne.

Vi oppsøkte gruppene i de siste kullene for å følge dem i prosessen i stedet for å vente på at de ba om hjelp. Til tross for at lærerne inntok en mer aktiv i rolle med å veilede under gruppearbeidsøktene, ble ikke veiledningen bedre evaluert av det siste kullet, sammenliknet med de foregående kullene. 


\section{三 «Når vi oppsøkte gruppene, ble det lettere for dem å uttrykke hva de hadde behov for veiledning i.»}

Vår erfaring er at det ikke var lett for studentene å vite hva de skulle spørre om på telefon eller per e-post, men når vi oppsøkte gruppene, ble det lettere for dem å uttrykke hva de hadde behov for veiledning i. At studentene ikke ble mer fornøyde med lærerveiledningen gjennom perioden, kan ha sammenheng med at lærerne selv følte seg utrygge på kvantitative forskningsmetoder.

\section{Studentene trengte mer metodekunnskap}

Tilstrekkelig metodekunnskap er en vesentlig forutsetning for å tolke forskningsresultater. Veilederen for undervisningsopplegget bidro med slik metodekompetanse med fellesundervisning i klasserommet når studentene la frem sin tolkning av forskningsartikkelen, og med rådgivning overfor lærerne.

Studentene evaluerte veilederens bidrag som «svært godt», og det har også vært til uvurderlig hjelp og støtte for lærerne. Likevel er følgende sitater eksempler på at lærerveiledningen ikke alltid møtte studentenes behov:

«Jeg synes at det kunne vært mer undervisning om de viktige temaene, og at man kunne fått tilstrekkelig hjelp når man hadde spørsmål.»

«Mer undervisning og veiledning, mindre tid på gruppearbeidet.»

«Skulle ha fått mer veiledning før vi fikk starte å jobbe [...], slik at vi visste at vi hadde forstått oppgaven [hva vi skulle gjøre] riktig.»

\section{KBP-nettkurs kan ha vært demotiverende}


Vi har tidligere vært inne på at metodekunnskap er en forutsetning for å lære KPB-prosessen. Studentenes metodekunnskap var på variabelt nivå, selv om nesten alle studentene hadde bachelor i sykepleie og gjennomførte KBP-nettkurset i en tidlig fase av undervisningsopplegget. Noen studenter har sykepleierutdanning av eldre dato og lærte ikke noe metode før jordmorstudiet.

En av studentene ønsket at undervisningen i KBP «på en eller annen måte kunne gjøres mer spennende». Det kan også tenkes at det har vært en demotiverende faktor for studentene at KBP-nettkurset var lagt opp som selvstudium. For de første kullene var det ikke satt av tid på timeplanen til dette kurset.

For det siste kullet ble det satt av én dag, men det var ikke lagt opp til lærerveiledning i løpet av denne dagen. Dermed ville vi ikke fange opp eventuelle studenter som fikk lite utbytte av kurset. Samtidig oppga altså tre firedeler av studentene at de hadde gode forutsetninger for å gjennomføre nettkurset.

\section{Integrering av KBP i praksis tok tid}

Fra et lærerperspektiv erfarer vi at studentene er mer motivert til å undervises i konkrete jordmorferdigheter, enn til å lære hvordan de skal finne og tolke forskningskunnskap, noe som kom til uttrykk i evalueringen fra flere studenter: «Synes også det var et dumt tidspunkt å ha dette på når man har lyst til å bruke tiden på patologi og forberede seg til viktige forelesninger.» 
Man kan si at jordmorfaget er relativt nytt i nasjonal akademisk-vitenskapelig sammenheng, da faget i stor grad har vært fundert på erfaringslære. Halvparten av studiepoengene i jordmorstudiet er praksisstudier og er omtrent jevnt fordelt gjennom hele utdanningen.

Studentene skal lære en ny profesjon, og det krever mye tid og arbeid i tillegg til å sette seg inn i forskning, og vi erfarer at de færreste studentene har tidligere erfaring med å innhente forskningskunnskap i læringen.

\section{三 «Studenter kan synes at veien virker lang for å oppnå et tilstrekkelig kunnskapsnivå i KBP.»}

Mange opplever at tid er en knapphetsressurs i jordmorutdanningen, og flere av studentene ga uttrykk for det i evalueringsskjemaet: «Synes det har tatt litt for mye tid, da vi skal ha eksamen neste år.»

Studenter kan synes at veien virker lang for å oppnå et tilstrekkelig kunnskapsnivå i KBP. Det er nødvendig med kunnskap i KBP for å bli i stand til å granske artikler og på sikt bidra til å implementere resultater fra forskningen i praksis.

Samtidig som studentene er godt motivert til å lære seg klinisk og praktisk jordmorfag, har vi inntrykk av at det er utfordrende for mange av dem å finne motivasjon til aktivt å integrere forskningen i læringsprosessen.

\section{Gruppearbeidet bød på utfordringer}

Gruppearbeid var en del av undervisningsopplegget, og gruppeprosessen er vesentlig for læring (17). For et av kullene var det imidlertid problemer med at medstudenter ikke møtte til gruppearbeidsøktene, slik at det ble mye arbeid for dem som møtte opp. 
Noen ønsket å sette sammen gruppene selv, og det ble rapportert om fravær og liten interesse for gruppearbeidet: «Jeg har syntes at det har vært utfordrende å være i en gruppe der det har vært mange som ikke har vært til stede under gruppearbeidet, slik at det har vært mye for dem som har arbeidet og møtt opp. Kanskje vi kunne valgt grupper selv?» og «Jeg ble skuffet over den lave interessen noen på gruppen viste og mener at dette gikk ut over egen læringsprosess».

Lærerne var ikke klar over at dette var et problem før undervisningsopplegget ble evaluert, og studentene kan ha en viss fraværsprosent uten at det får konsekvenser for dem. Samtidig var de aller fleste godt fornøyd med gruppearbeid som læringsverktøy for dette temaet: «[Det var] lærerikt å gjøre dette sammen med andre» og «Det var viktig med god diskusjon i gruppene».

\section{三 «Studenttilfredsheten med denne modellen er ikke er entydig positiv. "}

Det kan fremme læringen å forplikte seg sammen med medstudenter og bygge samhørighet, og i grupper kommer det frem flere perspektiver på saken (17). På den ene siden kan studentene velge grupper selv. På den andre siden kan en lærerstyrt gruppesammensetning som tilstreber at studenter med praksiserfaringer fra ulike nivåer i fødselsomsorgen er i samme gruppe, bidra til et større mangfold av faglige perspektiver i gruppene.

Studentenes samlede evaluering harmonerer med funn fra en systematisk oversiktsartikkel om flipped classroom-modellen, som viser at studenttilfredsheten med denne modellen ikke er entydig positiv (15).

\section{Oppsummering}


Undervisningsopplegget vårt har vektlagt at studentene skulle reflektere over praksiserfaringer, formulere spørsmål om fagutøvelse, finne og tolke forskning og integrere forskning i videre læring. Vi har erfart at studentene er mer motivert til å undervise i «rene» jordmorfaglige temaer. I tillegg opplever vi lærere at vår egen kompetanse i forskningsmetoder har vært noe mangelfull. Det har vært en klar svakhet i undervisningsopplegget.

I tillegg har lærerveiledningen kanskje ikke vært tett nok på studentenes arbeid. For tiden utarbeider utdanningen en ny masterstudieplan i jordmorfag. Erfaringene fra dette KBP-undervisningsopplegget har vært viktig, og KBP er integrert i ulike emner gjennom hele masterstudiet, som startet i august 2019.

\section{Referanser}

1. Bjørndal A, Flottorp S, Klovning A.

Kunnskapshåndtering i medisin og helsefag. 3. utg. Oslo: Gyldendal Akademisk; 2013.

2. Nortvedt MW, Jamtvedt G, Graverholt B, Nordheim LV, Reinar LM. Jobb kunnskapsbasert!: en arbeidsbok. 2. utg. Oslo: Akribe; 2012.

3. Meld. St. 13 (2011-2012). Utdanning for velferd. 2011-2012. Oslo: Kunnskapsdepartementet; 2012.

4. Helse- og omsorgsdepartementet.

HelseOmsorg21. Oslo; 2014. Tilgjengelig fra: https://www.helseomsorg21.no/ (nedlastet 25.11.2019).

5. Olsen NR, Lygren H, Espehaug B, Nortvedt MW, Bradley P, Bjordal JM. Evidence-based practice exposure and physiotherapy students' behaviour during clinical placements: a survey. Physiotherapy Research International. 2014;19(4):238-47. 
6. Weum M, Bragstad LK, Glavin K. Hvordan helsesøstre bruker kunnskapskilder. Sykepleien

Forskning. 2017;12(64242):(e-64242). DOI:

$\underline{10.4220 / \text { Sykepleienf.2017.64242 }}$

7. Snibsøer AK, Olsen NR, Espehaug B, Nortvedt MW. Holdning og atferd knyttet til kunnskapsbasert praksis. Sykepleien Forskning. 2012;7(3):(232-241).

DOI: $10.4220 /$ sykepleienf.2012.0129

8. Veeramah V. The use of evidenced-based information by nurses and midwives to inform practice. Journal of Clinical Nursing. 2016;25(34):340-50.

9. Munro J, Spiby H. Evidence based midwifery: applications in context. Chichester: Wiley-Blackwell; 2010.

10. Helsebiblioteket. Kunnskapsbasert praksis. Folkehelseinstituttet/Høgskulen på Vestlandet.

Oslo/Bergen; 2018. Tilgjengelig fra:

https://www.helsebiblioteket.no/kunnskapsbasertpraksis (nedlastet 10.03.2019).

11. Verdens helseorganisasjon. Facilitating evidence-based practice in nursing and midwifery in the WHO European Region 2017. Tilgjengelig fra: http://www.euro.who.int/en/health-topics/Healthsystems/nursing-andmidwifery/publications/2017/facilitating-evidencebased-practice-in-nursing-and-midwifery-in-the-whoeuropean-region-2017 (nedlastet 10.03.2019).

12. Melnyk BM, Fineout-Overholt E. Evidencebased practice in nursing \& healthcare: a guide to best practice. 3. utg. Philadelphia: Wolters Kluwer Health; 2015.

13. Alper BS, Haynes RB. EBHC pyramid 5.0 for accessing preappraised evidence and guidance. Evidence Based Medicine. 2016;21(4):123-5. 
14. Patelarou AE, Kyriakoulis K, Stamou AA, Laliotis A, Sifaki-Pistolla D, Matalliotakis M, et al. Approaches to teach evidence-based practice among health professionals: an overview of the existing evidence. Advances in Medical Education and Practice. 2017;8:455-64.

15. Betihavas V, Bridgman H, Kornhaber R, Cross M. The evidence for 'flipping out': A systematic review of the flipped classroom in nursing education. Nurse Education Today. 2016;38:15-21.

16. Polit DF, Beck CT. Nursing research:

generating and assessing evidence for nursing practice. Philadelphia: Wolters Kluwer Health; 2012.

17. Straus SE, Glasziou P, Richardson WS, Haynes RB. Evidence-based medicine. How to practice and teach it. 4. utg. Toronto: Churchill Livingstone; 2011. 